\title{
EFFECTIVENESS OF FIRM PERFORMANCE AND EARNINGS MANAGEMENT TO STOCK PRICES
}

\author{
Rieke Pernamasari ${ }^{1}$ \\ ${ }^{1,}$ Universitas Mercu Buana, \\ Jakarta Indonesia
}

\author{
Juita Tanjung ${ }^{3}$ \\ ${ }^{3,}$ Universitas Muhammadiyah Jakarta, \\ Indonesia.
}

\author{
Sri Purwaningsih ${ }^{2}$ \\ ${ }^{2}$ Universitas Mercu Buana, \\ Jakarta Indonesia
}

\author{
Dewi Puji Rahayu ${ }^{4}$ \\ ${ }^{4}$ Universitas Muhammadiyah Jakarta, \\ Indonesia.
}

\begin{abstract}
The long-term goal to be achieved in this research is to analyze stock prices by using firms performance and earnings management in the consumption sector manufacturing companies on the Indonesia Stock Exchange. Firm performance uses profitability proxies measured through Return On Assets (ROA) and leverage measured through Debt to Equity Ratio (DER), while the proxy for earnings management used is the actual specific model, namely working capital accruals. The stock price used in this study is the stock price one week after the publication date of the 2016-2018 financial statements. The results of the study indicate that the performance of companies proxied through ROA and DER is able to have a significant positive effect on stock prices in registered manufacturing sector manufacturing companies on the Indonesia Stock Exchange. The results of this study prove that investors are very concerned about the information contained in the financial statements published by the company, especially information about profits or profits obtained by the company and the debt used by the company for its operations, while earnings management is able to give an influence but not significant on stock prices. This means that investors do not respond to information, including accruals in the financial statements.
\end{abstract}

KEYWORDS: Return on Asset, Debt on Equtity Ratio, Earning Management, Stock Price.

\section{INTRODUCTION}

In the modern era, stock investment has become one of the various investment options that is quite attractive to foreign and local investors. Supported by clear regulations, a high level of security, and easy access to the stock market, stocks as an investment instrument are not only demanded by upper-class investors, but also attract the interests of small investors.

Besides being influenced by the law of demand and supply, the company's performance also determines the high and low prices of shares in the capital market. (Rahmawati \& Handayani, 2017) said the stock price reflects the collective assessment of investors of a company's current performance and future prospects. When the market is more optimistic about companies, high prices make it easier for companies to increase capital, so stock prices play a major role in the allocation of capital in the economic market, directing capital to companies and applications with the greatest potential for perception.
It is difficult to point out that only one or two factors affect stock prices, for example financial policy, monetary policy, foreign trade policy and other macroeconomic factors, financial information and other internal factors. However, from these factors, financial information is one of the main elements used by investors in making decisions, (Maryyam Anwaar, 2016).

(Ardian \& Khoiruddin, 2014) in his research said investors have various considerations to decide on an investment in the stock market, one of which is the company's financial condition contained in the annual report. However (Cai \& Zhang, 2011) say the choice of capital structure is one of the most important decisions faced by managers, and changes in leverage ratios can affect funding capacity, risk, capital costs, investment and corporate strategic decisions, and ultimately shareholder wealth. (Bahreini et al, 2013) Economic managers believe that financial leverage is one of the most important factors in managing capital. The company's capital structure is the relationship 
between debt and the rights of shareholders who will get the financial support they need. So managers will be very careful in accepting loans and the impact they will have. If a company achieves good condition by receiving a loan (leverage has been good), the profit from each shareholder will increase, of course it will have an impact on the share price, (Ozturk \& Yilmaz, 2015).

However, these results contradict the results of the study (Dzulqodah \& Mujati, 2016), leverage measured through DER has a positive effect on stock prices because the company's strategy in funding utilizes debt to reduce tax burden. The use of debt in a larger amount will reduce taxes and cause more operating profit (EBIT) of the company to flow to investors. In addition, when the company's activities get higher it can be pointed out that its products are able to penetrate the targeted market and will bring higher profit levels. So even though the Debt to Equity Ratio (DER) is high, the profit flowing to investors remains high which causes the stock price to be high

(Saeidi \& Okhli, 2012) in their research on the Tehran Stock Exchange company produces ROA has a high correlation with stock prices at the level of all industries, and it can be used as the main effective factors affecting stock prices. In other words, the findings of this ratio test can be used in the analysis of users of financial statements and investors as an index to compare with other stocks. Similar to the results of the study (Bintara \& Tanjung, 2019), companies with good asset returns have the potential to attract companies by investors. This condition makes the company's stock price rise so that there is an increase in stock returns. However, research (Warrad and Omari, 2015) produces ROA does not affect the stock prices of mining companies on the Stock Exchange, according to him investors tend to see how much profit will be generated per share strip rather than to find out how companies manage their assets into profits.

Because profits are the main goal of investors, managers are able to do earnings management. Earnings management occurs when managers use valuations in financial reporting and in preparing transactions to change financial statements to mislead some stakeholders about the economic performance of the underlying company or to influence the outcome of contracts that depend on the accounting numbers reported, (Jiang et al, 2017). Will (Ghazali et al, 2015) add that if earnings information is used by managers to convey superior and useful information that they know about the company's performance to shareholders and debt holders, then earnings management may not be harmful to shareholders and the public. However, the financial scandal at WorldCom and Enron turned the earnings management view into an opportunistic view. With regard to this view, managers manage income for their own personal benefit rather than for the benefit of shareholders
In agency theory (Jensen \& Meckling, 1976), management implements accountability to shareholders, this implies that the company system employed is designed to make shareholders truly aware of the company's financial performance and potential. As expressed (Rahimipour, 2017) a relationship can be found between accounting items with managers who have the ability to manipulate them such as discretionary accruals and stock returns. Developing company managers have more incentive and motivation for signaling on confidential information about the company's future performance through discretionary accruals. As a result, investors will recognize incentives and motivations and will be rewarded for this information which is reflected in stock prices.

Based on the phenomena and background of various research results above, it can be reexamined for factors that affect stock prices. In this study, firm performance is a factor reflected in ROA and DER and earnings management factors which are the result of manager's actions.

\section{LITERATURE REVIEW Signaling Theory.}

The signal is an action taken by the company to give instructions to investors about how management views the company's prospects. According to (Brigham \& Houston, 2013) Information released by companies is important, because of its effect on investment decisions of parties outside the company. This information is important for investors and business people because the information essentially presents information, notes or pictures, both for past, present and future conditions for the survival of the company and how it affects the company. Information is an important element for investors and business people because the information essentially presents information, notes or pictures both for the past, present and future conditions for the survival of a company and how the market effects.

Signal theory based on earnings management is a financial communication tool as outlined by (Sayari, Mraihi, Finet, \& Omri, 2013), earnings management makes investors wrong and maintains the thesis that the value of information from published results is enriched. However other researchers support the idea that earnings management is an attempt to deceive stakeholders, such as the possibility to reduce the value of information from published results through potential interference in earnings management motivation.

\section{Agency theory}

Agency theory states that there is an agency relationship as a contract between management as an agent and ownership as a company preliminary, a working relationship between the party that gives authority (preliminary), namely the shareholders and 
the recipient authority (agent) of the company in the form of cooperation, (Jensen \& Meckling, 1976 ). The agent has more information about his capacity, work environment and the company as a whole. This has resulted in an imbalance of information between the principal and the agent, which is called information asymmetry. This information asymmetry and conflict of interest encourage agents to present false information to the principal, especially if the information is related to the agent's performance.

\section{Stock Prices}

According to (Kamaludin, Indriani, 2012: 235) shares can be defined as a sign of ownership or ownership of a person or entity in a company. (Andirawan \& Salean, 2016) said the stock price was formed in the capital market and determined by several factors, one of which is the financial ratios in the financial statements. Share prices can affect investors' decisions to invest in publishing companies, (Endri \& Yerianto, 2019).

Roykhan in (Marcelina \& Yuliandhari, 2014) said that the stock price is a very important factor and must be considered by investors in investing because the stock price shows the issuer's achievements, stock price movements are in line with the issuer's performance. If the issuer has better performance, the profits that can be generated from operating the business will be even greater. In such conditions, the share price of the issuer concerned tends to rise.

This study uses stock prices taken one week after the date of publication of the financial statements (the period). According to (Hartono, 2010) published information that affects the price of securities of companies that publish that information. This published information is information in the form of announcements by issuers. Announcements that can affect the price of securities are, among other things, announcements related to earnings. So that it will affect investors in making decisions to invest.

\section{Firm performance}

Firm performance is the result of management or team activities, these results are or the overall level of success during a certain period in carrying out the task. The company's performance is also a formal effort that has been done by a company that can measure the company's success in generating profits, so that it can see the prospects, growth, and the potential for good development of the company by relying on existing resources. A company can be said to be successful if it has reached the standards and objectives that have been set, (Subramanyan, 2014).

Measurement of firm performance is one indicator used by investors to assess a company from the market price of the shares on the stock market. The better the company's performance, the higher the returns that will be obtained by investors. Generally investors will look for companies that have the best performance and invest their capital in these companies. In this study, firm performance is measured through operational performance, namely profitability ratios through ROA and leverage ratios through DER.

\section{Return on Asset (ROA)}

Return on Assets is a measure of a company's ability to generate profits with all assets owned by the company. These assets are all of the company's assets starting from its own capital or foreign capital that has been converted into company assets for the survival of the company. This ratio figure is commonly used to measure a company's performance by investors. The increased return on assets shows how well assets are managed by the company to bring profit for every one dollar of assets that have been invested in the company, (Atidhira \& Yustina, 2017).

Economically, the higher the rate of return obtained, the higher the company's ability to utilize its assets to make a profit. So that the higher ROA, the higher the company's ability to generate profits the higher the company's revenue will make investors interested in the value of shares, (Warrad \& Omari, 2015).

\section{Debt to Equity Ratio (DER)}

The leverage ratio describes the source of operating funds used by the company. The leverage ratio also shows the risks faced by the company. The greater the risk faced by the company, the uncertainty to generate profits in the future will also increase, (Agustia, 2013). The consequence of the use of leverage according to (Cai \& Zhang, 2011) is if from the use of debt it turns out that the rate of return on assets (return) is greater than the cost of debt, the leverage is profitable and the return on capital by using this leverage also increases, vice versa if the returns for assets smaller than the cost of debt, then leverage will reduce the rate of return on capital.

(Utami \& Darmawan, 2019) said that DER is one measure of leverage ratio that can be defined as the level of debt use as a source of corporate financing. From the perspective of the ability to pay long-term obligations, the lower the DER will have an impact on rising share prices and also the company will be better at paying long-term obligations. Information about increasing the DER will be received by the market as a bad signal that will provide negative input to investors in making a decision to buy shares. This makes the demand and the share price go down.. 


\section{Earning Management}

Copeland, 1968 (Utami, 2005) defines earnings management as "the same ability to increase or decrease reported net income at will", this means that earnings management includes management efforts to maximize or minimize earnings including earnings equipment in accordance with management desires . Earnings management is done to influence investors' perceptions, especially to influence the company's stock buying decisions.

(Zang, 2012) says Accrual earnings management tends to be done by managers after the fiscal year ends. Some managers may find it very expensive because their companies face intense competition in the industry. In an industry, companies tend to face various levels of competition and, therefore, come under different amounts of pressure when deviating from the optimal business strategy. Therefore, managers in market leader companies may consider manipulation of real activities cheaper because the erosion of their competitive advantage is relatively small.

If it is associated with an increase in the value of the company, (Syanthi et al, 2017) said when there is information asymmetry, managers can give signals about the condition of the company to investors in order to maximize the value of the company's shares. The signal given can be done through the disclosure (disclosure) of accounting information.

Furthermore (Roychowdhury, 2006) revealed several techniques that can be done in the manipulation of real activities, including sales manipulation, overproduction, and reducing the cost of discretion. With the tendency of managers to seek their own benefits (moral hazard) and a high level of information asymmetry, plus certain motives, increasing the likelihood of management utilizing accrual items to present earnings in accordance with management interests that may not be in accordance with principal interests, such as owner, shareholder, or lender.

To find out whether there is earnings management, (W. Utami, 2005) reveals the measurement of accruals is very important to note. Total accruals is the difference between earnings and cash flows from operating activities. Total accruals can be divided into two parts, namely (1) the part that naturally exists in the process of preparing financial statements and (2) the accrual part which is a manipulation of accounting data called abnormal accruals.

In this study the proxy for earnings management used is the actual specific model of working capital accruals. The use of working capital accruals is more appropriate as has been reviewed by (W. Utami, 2005). Because discretionary accruals are considered to be more complicated, a proxy for working capital accruals with sales is used. The reason is because earnings management occurs in many sales accounts. Working capital accrual data can be obtained directly from the statement of cash flows from operating activities, so investors can directly obtain the data without making complicated calculations

\section{HYPOTHESIS \\ Effect of ROA to Stock Prices}

ROA is the company's ability to manage its assets into profits, management can use the company's total assets (current assets and fixed assets) to attract many investors to invest. The ability of ROA in predicting stock prices is possible because the nature and pattern of ROA carried out by the company is very precise so that there are several assets that are worked on or used efficiently so as to obtain the maximum stock price. So that the relationship between ROA and stock prices is positive and significant, which means that there is an increase in ROA can increase share prices, (Manoppo, 2015)..

H1: ROA has significant positive effect to stock prices

\section{Effect of DER to Stock Prices}

DER is a measure of leverage ratio that can be defined as the level of debt used as a source of corporate financing. From the perspective of ability to pay long-term obligations, the lower the DER will have an impact on rising share prices and also the company will be better at paying long-term obligations. Information about the increase in DER will be received by the market as a bad signal that will provide negative input to investors in making decisions to buy shares, this makes demand and share prices fall, (Utami \& Darmawan, 2019)..

H2: DER has significant negative effect to stock prices.

\section{Effect of Earning Management to Stock Prices}

Earnings management occurs when managers use valuations in financial reporting and in preparing transactions to change financial statements to mislead some stakeholders about the economic performance that underlies the company or to influence the outcome of contracts that depend on reported accounting numbers, (Ghazali et al, 2015). According to Copeland, 1968 in (W. Utami, 2005) earnings management includes management efforts to maximize or minimize earnings including earnings equipment in accordance 
with management's wishes. Earnings management is done to influence investors' perceptions, especially to influence the company's stock buying decisions.

H3: Earning has significant positive effect to stock prices.

Figure 1. Framework

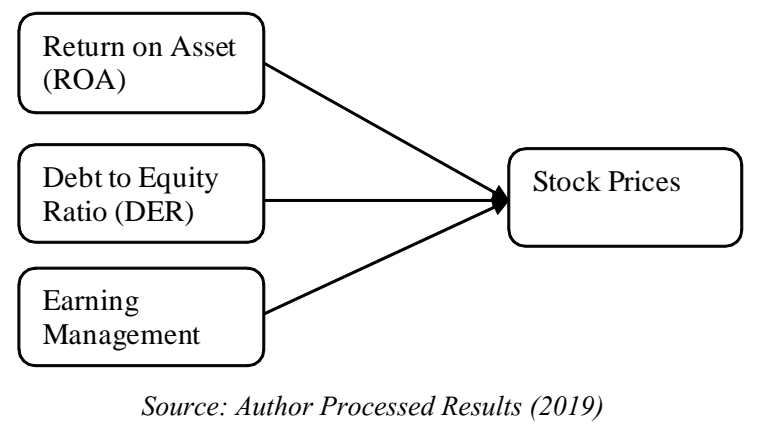

\section{RESEARCH METHODS} Types of research

The design used in this study is causal research. Causal research aims to determine the effect or also the relationship between two or more variables (Sugiyono, 2013)

\section{Research Population and Samples}

The population of this study is the consumption sector manufacturing companies listed on the Indonesia Stock Exchange, with an observation year of 2016-2018.
The number of consumption sector manufacturing companies listed on the IDX successively in 2016 to 2018, as many as 22 companies

The sampling technique used in this study is the purposive sampling method, where the sample is chosen based on the suitability of the characteristics with the criteria (consideration) of the sample determined to obtain a representative sample. The sample of this research is 22 companies multiplied by the number of years of observation, so the total sample is 66 data

Table 1.Sample Measurement

\begin{tabular}{llr}
\hline No. & \multicolumn{1}{c}{ Keterangan } & Jumlah \\
\hline 1. & $\begin{array}{l}\text { Manufacturing companies of sector Consumption listed on the IDX period } 2016- \\
\text { 2018 consistently }\end{array}$ & 22 \\
\hline 2. & Companies that do not have complete indicator components.. & $(0)$ \\
\hline 3. & Samples & 22 \\
\hline 4. & Data (22 x 3 research year) & 66 \\
\hline Source: Author Processed Results
\end{tabular}

Definition and Operationalization of

Variables

Variabel Dependent

Stock Prices

Stock price used is the closing price of the consumer sector manufacturing company which is taken one week after the date of publication of the financial statements (the period), which is where the date of publication of the financial statements is obtained from the IDX.

\section{Variabel independent \\ Return on Asset (ROA)}

ROA are ratios that describe a company's ability

to generate profits through all its capabilities and resources, which are derived from sales activities, asset use, and capital use.

Debt to Equity Ratio (DER)

DER is a comparison between debt and equity about company funding which shows the ability of own capital to fulfill all obligations..

\section{Management Laba}

$$
\text { Debt to Equty Ratio }(D E R)=\frac{\text { Total of Debt }}{\text { Equity }}
$$

Earnings management is proxied based on the ratio of working capital accruals to sales (Utami, 2005). Earnings management $(\mathrm{EM})=$ Working capital accrual $(\mathrm{t})$ / Sales period $(\mathrm{t})$ working capital accruals $=\Delta \mathrm{CA}-\Delta \mathrm{CD}-\Delta \mathrm{CE}$ 
Info:

$\triangle C A=$ change in current assets in period $\mathrm{t}$

$\triangle C D=$ changes in current debt in period $\mathrm{t}$

$\Delta \mathrm{CE}=$ changes in cash and cash equivalents in period $\mathrm{t}$

Working capital accrual data can be obtained directly from the statement of cash flows from operating activities, so investors can directly obtain the data without performing complex calculations. The formula for calculating company size or size can use the following size.

\section{Variabel kontrol}

The researcher adds the size control variable with the main reason to prevent the influence of the independent variable on the dependent variable not being influenced by external factors under study.. Size company $=$ Ln (total Asset)

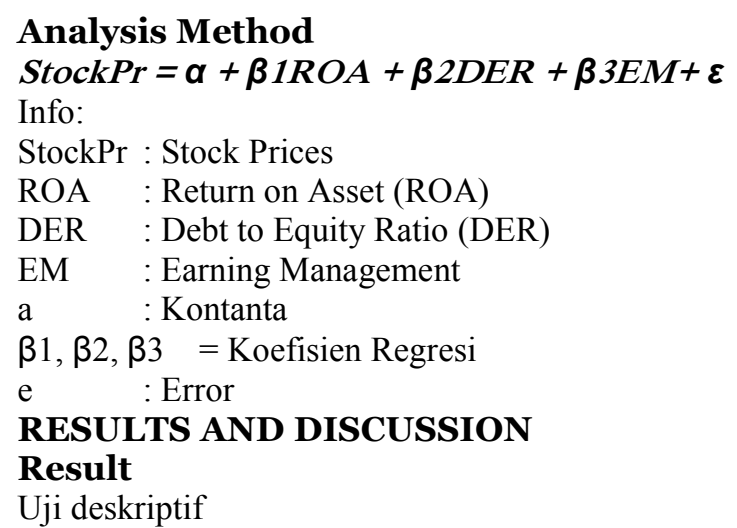

Tabel 2.Results of Descriptive Statistics Analysis

\begin{tabular}{|c|c|c|c|c|c|}
\hline & $\mathbf{N}$ & Minimum & Maximum & Mean & Std. Deviation \\
\hline ROA & 66 & .028 & .920 & .15207 & .15424 \\
DER & 66 & .080 & 2.640 & .59333 & .529570 \\
Earning & 66 & -.7595 & 1.0412 & .019070 & .1788699 \\
Management & 66 & 185 & 84475 & 10466.55 & 19855.760 \\
Stock Price & 66 & & & \\
Valid N (listwise) & 66 & & & \\
\hline
\end{tabular}

Source data: SPSS.22

Based on the table above, it can be seen the variables with the number of data $(\mathrm{N})$ each of 66 are described as follows:

The performance of companies represented through ROA has a minimum value of $2.8 \%$, namely $\mathrm{Pt}$. Chitose International Tbk and has a maximum value of $92 \%$, namely Pt Merk Tbk. On average, the manufacturing sector manufacturing companies have an ROA value of $15 \%$, this means the company can generate a net profit on assets owned by $15 \%$, due to the high sales growth that results in higher profits than the total assets.

The performance of companies represented through DER has a minimum value of $8 \%$, namely $\mathrm{Pt}$ Sido Muncul Tbk and has a maximum value of $264 \%$ by $\mathrm{Pt}$ Unilever Tbk. On average the consumption sector manufacturing companies have a value of $59 \%$, this means that companies use more equity to fund the needs of the company.

Earnings management is the company's manager's effort to intervene or influence the information in the financial statements. Obtained a minimum value of -0.75, namely Pt Merk Tbk and has a maximum value of 1.04, namely Pt Ultrajaya Tbk. On average the consumption sector manufacturing companies have a value of 0.019 , this means that management has $1.9 \%$ in influencing the company's operations.

The share price of manufacturing sector consumption companies with a minimum value of 185 namely Pt Pyridam Farma Tbk and a maximum value of 84475 namely Pt Sampoerna Jaya Tbk.

Uji Asumsi Klasik

Table 5 Classical Assumption Test Results

\begin{tabular}{|c|c|c|c|c|}
\hline \multicolumn{5}{|c|}{ Uji Statistik Result } \\
\hline Model & $\boldsymbol{B}$ & Sig Uji t & Tolerance & VIF \\
\hline Constant & 1.213 & & & \\
\hline$R O A$ & -0.239 & 0.093 & 0.706 & 1.417 \\
\hline$D E R$ & -0.089 & 0.486 & 0.916 & 1.091 \\
\hline$M L$ & -0.496 & 0.375 & 0.908 & 1.101 \\
\hline SIZE & -0.037 & 0.051 & 0.736 & 1.360 \\
\hline \multicolumn{5}{|l|}{ Dependent Variable: $A B S$} \\
\hline Asymp. Sig. (2-tailed) Normalitas & 0.074 & & & \\
\hline Sig Runs Test & 0.215 & & & \\
\hline
\end{tabular}

Source: Data processed with SPSS.22 
Based on table 5 above, the results of the classic assumption test show that the data has passed the classic assumption test. data is normally distributed because it has an asymp value of sig $>0.05$. The results of the auto correlation test use the runs test and show that the data does not occur autocorrelation because the sig runs test results $>0.05$. The results of heterokedacity using glacier test and showed that the value of sig $>0.05$ so that it can be said that the independent variable is free from heterokedacity. Multicollinearity test results show Tolerance values $>0.1$ and VIF values less than 10 so that it can be said that the data is free from multicollinearity.

\section{Model Feasibility Test}

Table 6 Model Feasibility Test Results Uji Statistic Result

\begin{tabular}{lcc}
\hline Model & B & Sig Uji t \\
\hline Constant & 11.173 & 0.000 \\
ROA & 0.861 & 0.012 \\
$M L$ & 0.554 & 0.818 \\
SIZE & 0.214 & 0.241 \\
Dependent Variable: Harga Saham & -0.035 & \\
Sig Uji F & & \\
R Adjusted Square & 0.000 & \\
\hline
\end{tabular}

\section{Sumber: Olah data SPSS.22}

Based on the feasibility test results table the model shows that simultaneously all independent variables together have an influence on the dependent variable because the value of the $F$ test results $<0.05$. For the results of the $t$ test show the company's performance variables measured through return on assets (ROA) and Debt to Equity Ratio (DER) produce a significant positive effect on stock prices, while earnings management variables show no significant positive effect on stock prices. So it can be concluded that Hypothesis 1 can be accepted while hypotheses 2 and 3 cannot be accepted..

If look at the value of $\mathrm{R}$ Square, it can be said that the independent variable in predicting the dependent variable stock price is $39.7 \%$, while the remaining $60.3 \%$ is influenced by other variables outside the study.

\section{Multiple Regression Test}

\section{Analysis model}

StockPr $=11.173+0.861 \mathrm{ROA}+0.554 \mathrm{DER}+$ $0.214 \mathrm{ML}+\mathrm{e}$

From the above results it can be said that if there is no variable that affects the value of the share price of the manufacturing sector manufacturing companies is 111743. If there is an additional 1 point from the variable ROA, it will increase the value of the stock price by 0.861 . Then if there is an addition of 1 point from the DER variable it will increase the value of the stock price by 0.554 . Then if there is an addition of 1 point from the earnings management variable, it will increase the value of the stock price by 0.214

\section{DISCUSSION \\ The Effect ROA to Stock Prices}

Hypothesis test results show that ROA has a significant positive effect on stock prices in manufacturing sector manufacturing companies listed on the Indonesia Stock Exchange (IDX). The results show a positive direction that can be said that when the company's profits shown in the financial statements are high, then the company's stock market price will tend to rise because it is influenced by the stock market value and investors' perceptions about the company so that it will affect the demand and supply of shares in the secondary market. These results suitably support signal theory which is a guide for investors to assess the company's prospects.

As the results of research (Manoppo, 2015) which says that the ability of ROA in predicting stock prices is possible because the nature and pattern of ROA conducted by the company is very precise so that there are some assets that are worked on or used efficiently so as to obtain maximum stock prices.

\section{The Effect DER to Stock Prices}

Hypothesis test results indicate that DER has a significant positive effect on stock prices in manufacturing sector manufacturing companies listed on the Indonesia Stock Exchange (IDX). These results indicate that the composition of debt (short term and long term) is getting bigger along with investor confidence in the company, where the debt is able to be used for the sustainability of the company which in turn will improve the performance of normal shareholders. The greater the leverage the greater the risk of the company, but insofar as the company has a special place in managing capital structure, it becomes a concern for investors which is 
reflected in the stock price. This happens because the manufacturing sector manufacturing companies are products that are indeed needed by the community to meet their daily needs, so the sales target is allegedly achieved. So even though the DER is high, the profit flowing to investors remains high which causes the stock price is also high.

(Dzulqodah \& Mujati, 2016) said the use of larger amounts of debt would reduce taxes and cause more company operating income (EBIT) to flow to investors. In addition, when the company's activities get higher it can be pointed out that its products are able to penetrate the targeted market and will bring higher profit levels.

As said (Bahreini et al, 2013) Economic managers believe that financial leverage is one of the most important factors in managing capital. The company's capital structure is the relationship between debt and the rights of shareholders who will get the financial support they need. So managers will be very careful in accepting loans and the impact they will have. If a company achieves good condition by receiving a loan (leverage is good), the profit from each shareholder will increase, of course, it will have an impact on the stock price..

\section{The Effect Earning Management to Stock Prices}

Hypothesis test results show the results that earnings management does not have a significant positive effect on stock prices. These results conclude that companies that achieve earnings management by manipulating operating cash activities through profitability of selling assets, current debt and current assets have an influence on future performance in one year, two years, and three years but will not cause in the long term short. Larger companies lack the drive to act aggressively and opportunistically manage earnings through operational activities, although manipulation through operating cash activities has proven difficult to detect, but because they are seen as more critical by outside shareholders, the push for opportunistic and aggressive action is suppressed. In theory, if a company carries out earnings management by making income smoothing and growth, it can increase published profits.

According to (Uswati \& Mayangsari, 2016) high management awareness of the risk of aggressive manipulation is likely to be a special consideration so as not to be manipulated with real activities aggressively. The possibility of internal supervision is one of the factors that can reduce agency conflict, thereby minimizing earnings management and making management not acting opportunistically by carrying out real manipulations.

\section{CONCLUSION}

1. Firm performance as measured by return on assets and Debt to Equity Ratio influence the ups and downs of stock prices in the capital market in the consumption sector manufacturing companies on the Indonesia Stock Exchange. This indicates that investors are very concerned about the information contained in the financial statements published by the company, especially information about profits or profits obtained by the company and the debt used by the company for its operations.

2. Earnings management has no influence on the rise and fall of stock prices in the consumption sector manufacturing companies on the Indonesia Stock Exchange. This means that investors do not respond to information, including accruals in the financial statements.

\section{SUGGESTIONS}

For investors and creditors the results of this study are expected to be able to provide investment decisions, namely by paying attention to the elements of financial ratios and accrual information in a company. For management, this result is expected to be an input for corporate accountability.

\section{REFERENCE}

1. Agustia, D. (2013). Pengaruh Faktor Good Corporate Governance, Free Cash Flow, dan Leverage Terhadap Manajemen Laba. Jurnal Akuntansi Dan Keuangan, 15(1), 27-42. https://doi.org/10.9744/jak.15.1.27-42

2. Andirawan, N. F., \& Salean, D. (2016). Analisis Metode Altman Z-Score Sebagai Alat Prediksi Kebangkrutan Dan Pengaruhnya Terhadap Harga Saham Pada Perusahaan Farmasi Yang Terdaftar Di Bursa Efek Indonesia. Jurnal Ekonomi Akuntansi, 1(1),67-82

3. Ardian Andromeda, \& Khoiruddin, M. (2014). Pengaruh Analisis Kebangkrutan Model Altman Terhadap Harga Saham Perusahaan Manufaktur. Management Analysis Journal, 3(1), 1-14. https://doi.org/10.15294/maj.v3i1.3354

4. Atidhira, A. T., \& Yustina, A. I. (2017). The Influence of Return on Asset, Debt to Equity Ratio, Earnings per Share, and Company Size on Share Return in Property and Real Estate Companies. JAAF (Journal of Applied Accounting and Finance), 1(2), 128-146. Retrieved from http://www.bi.go.id

5. Bahreini, V., Baghbani, M., \& Bahreini, R. (2013). Analysis between financial leverage with the stock price and the operational performance of the accepted companies in Tehran's stock market. European Online Journal of Natural and Social Sciences, 2(3), 25-34.

6. Bintara, R., \& Tanjung, P. R. S. (2019). Analysis of Fundamental Factors on Stock Return. International Journal of Academic Research in Accounting, Finance and Management Sciences, 9(2), 49-64. https://doi.org/10.6007/IJARAFMS/v9-i2/6029

7. Brigham, Eugene F., Houston, J. F. (2013). Essential of Financial Management (11th ed.). Jakarta: Salemba Empat.

8. Cai, J., \& Zhang, Z. (2011). Leverage Change, Debt Capacity, and Stock Prices. SSRN Electronic Journal, (April). https://doi.org/10.2139/ssrn.1107878

9. Dzulqodah, M., \& Mujati, Y. (2016). PENGARUH EARNING PER SHARE DAN PRICE EARNING Ratio Terhadap Debt To Equity Ratio Dan Harga 
10. Saham Pada Perusahaan Sektor Makanan Dan Minuman Di Bursa Efek Indonesia. Jurnal EKSIS, $X I(1), 102-123$.

11. Ghazali, A. W., Shafie, N. A., \& Sanusi, Z. M. (2015). Earnings Management: An Analysis of Opportunistic Behaviour, Monitoring Mechanism and Financial Distress. Procedia Economics and Finance, 28(April), 190-201. https://doi.org/10.1016/s2212 5671(15)01100-4

12. Hartono, J. (2010). Teori Portofolio dan Analisis Investasi (7th ed.). Jogyakarta: BPFE Jogyakarta.

13. Jensen, M. C., \& Meckling, W. H. (1976). THEORY OF THE FIRM: MANAGERIAL BEHAVIOR, AGENCY COSTS AND OWNERSHIP STRUCTURE. Journal of Financial Economics, 3(4), 305-360. https://doi.org/10.1002/mde.l218

14. Jiang, J., Liu, Q., \& Sun, B. (2017). Earnings Management and Stock Returns: Theory and Evidence. In Federal Reserve Board, Mid- West Theory Conference, and Royal Economic Society.

15. Kamaludin,. Indriani, $R$. (2012). Manajemen Keuangan "Konsep Dasar dan Penerapannya." Bandung: CV. Mandar Maju.

16. Manoppo, C. P. (2015). The Influence of Roa, Roe, Ros, and Eps on Stock Price. Jurnal Riset Ekonomi, Manajemen, Bisnis Dan Akuntansi, 3(4), 691-697

17. Marcelina, T. A., \& Yuliandhari, W. S. (2014).

18. Prediksi Kebangkrutan Menggunakan Metode ZScore Perusahaan Transportasi Yang Terdaftar Di Bursa Efek Indonesia Tahun 2008-2012 Bankruptcy Prediction Using Z-Score Methods and Its Influence on Share Prices of Transportation Companies List on the Indonesia. E-Proceeding of Management, 1(3), 291-298.

19. Maryyam Anwaar. (2016). Impact of Firms' Performance on Stock Returns (Evidence from Listed Companies of FTSE-100 Index London, UK). Global Journal of Management and Business Research: D Accounting and Auditing, 16(1), 678-685.

20. Ozturk, H., \& Yilmaz, A. A. (2015). Leverage and Stock Returns: Evidence from Istanbul Stock Exchange. Accounting and Finance Research, 4(4), 140-146. https://doi.org/10.5430/afr.v4n4p140

21. Rahimipour, A. (2017). Investigating the validity of signaling theory in the Tehran stock exchange: Using real earnings management, accrual-based earnings management and firm growth. International Journal of Economic Perspectives, 11(3), 925-936.

22. Rahmawati, F. I., \& Handayani, S. R. (2017). The Influence Of Good Corporate Governance Practice On The Stock Price (Study on Company of LQ45
Index in Indonesia Stock Exchange during 20122016). Administrasi Bisnis, 50 No. 6(6), 164-173. Retrieved from

23. https://www.neliti.com/id/publications/189320/theinfluence-of-good-corporate-governance-practice-onthe-stock-price-study-on

24. Roychowdhury, S. (2006). Earnings management through real activities manipulation. Journal of Accounting and Economics, 42(3), 335-370. https://doi.org/10.1016/j.jacceco.2006.01.002

25. Saeidi, P., \& Okhli, A. (2012). Studying the effect of assets return rate on stock price of the

26. companies accepted in Tehran stock exchange. Business and Economic Horizons, 8, 12-22. https://doi.org/10.15208/beh.2012.7

27. Sayari, S., Mraihi, F., Finet, A., \& Omri, A. (2013). The Impact of Earnings Management on Stock. Global Journal of Management and Business Research Finance, 13(10), 51-65.

28. Subramanyan, K. R. (2014). Financial Statement Analysis (Eleventh E). Singapore: Mc Graw Hill.

29. Sugiyono. (2013). Metode Penelitian Kuantitatif, Kualitatif, dan R\&D. Bandung: Alfabeta.

30. Syanthi, N. T. T., Sudarma, M., \& Saraswati, E. (2017). Dampak Manajemen Laba Terhadap Perencanaan Pajak Dan Persistensi Laba. EKUITAS (Jurnal Ekonomi Dan Keuangan), 17(2), 192. https://doi.org/10.24034/j25485024.y2013.v17.i2.224 8

31. Uswati, L., \& Mayangsari, S. (2016). Pengaruh Manajemen Laba Terhadap Future Stock Return Dengan Asimetri Informasi Sebagai Variabel Moderating. Ekuitas: Jurnal Ekonomi Dan Keuangan, 20(2), 242-259.

32. Utami, M. R., \& Darmawan, A. (2019). Effect of DER , ROA , ROE , EPS and MVA on Stock Prices in Sharia Indonesian Stock Index. Journal Of Applaied Accounting and Taxation, 4(1), 15-22.

33. Utami, W. (2005). Pengaruh Manajemen Laba Terhadap Biaya Modal Ekuitas (Studi Pada Perusahaan Publik Sektor Manufaktur). SNA VIII Solo 15-16 September 2005, 100-116.

34. Warrad, L., \& Omari, A. R. (2015). Effect of Earning Per Share (EPS) and Return On Assets (ROA) Against Share Price on Coal Mining Company Listed in Indonesia Stocks Exchange. Journal of Resource Development and Management, 7(6), 79-92.

35. Zang, A. Y. (2012). Evidence on the trade-off between real activities manipulation and accrual-based earnings management. Accounting Review, 87(2), 675-703. https://doi.org/10.2308/accr-10196 